\title{
LITHOLOGIC CHARACTERISATION OF THE BASEMENT AQUIFERS OF AWE AND AKINMORIN AREAS, SOUTHWESTERN NIGERIA
}

\section{OLANREWAJU A. AKANBI AND OLAITAN J. OLUKOWADE}

(Received 2 February 2017; Revision Accepted 4 August 2017)

\begin{abstract}
Just like many communities in Nigeria, people living in Awe and Akinmorin areas rely on groundwater supply for their domestic water need. However, these areas are underlain by impermeable crystalline rocks that included migmatite, schist and quartzite that can only transmit water when fractured and where there is sufficient weathered regolith overlying the bedrocks. Therefore, a total of twenty-five vertical electrical soundings (VES) was conducted across the study area with the aim of investigating the lithological characteristics of the regolith and the underlying bedrocks for groundwater prospect.

An aggregate of nine soundings were conducted on quartzite terrains and eight each across terrains underlain by migmatite and schist. From the VES results, the dominant curves across the study areas were the $\mathrm{H}$ and $\mathrm{KH}$ types. These geo-electric curves indicate that the middle (saprolite) layers are more conductive and the bedrocks are more resistive. The total regolith thickness ranged from 11.9 to $50.9 \mathrm{~m}$ with an average of $26.4 \mathrm{~m}$ on migmatite terrains, 11.7 to $28.8 \mathrm{~m}$ and average of $19.4 \mathrm{~m}$ on schist terrain and 8.4 to $41 \mathrm{~m}$ with an average of $22.3 \mathrm{~m}$ on quartzite terrain. From the lithologic characterisation, $70 \%$ of the saprolite layers are interpreted as fine grained with resistivities of less than $100 \Omega \mathrm{m}$, which is an indication of deep and intense weathering across the study area. The occurrences of fractured and fresh bedrocks are almost of the same proportions. However, there is more dominant of partially weathered bedrocks than those that are either fresh or fractured. Altogether, bedrocks resistivities of more than half of the surveyed area are $<1500 \Omega \mathrm{m}$ and were either fractured or slightly weathered. This increased groundwater prospect across the study area, particularly within terrains underlain by fractured bedrocks.

Generally, the potential for groundwater development in the study area is reasonably credible. Although, the saprolite units are mostly fine grained and may not be the best groundwater bearing zone, they may act as confining units for areas underlain by fractured or partially weathered bedrocks. In addition, the fairly thick fine grained saprolite layer may reduce the risk of groundwater contamination from direct recharge.
\end{abstract}

KEYWORDS: Groundwater, Saprolite, Bedrock, Lithology

\section{INTRODUCTION}

Groundwater is the main water supply in most developing nations, particularly in Nigeria where piped water is not within the reach of many people (Akanbi, 2016). Siting of productive wells in basement complex terrain remains a challenging and expensive task because fracture and weathering development at the regional scale is not homogenous and isotropic (Manda et al., 2006).

Awe and Akinmorin areas are entirely underlain by crystalline basement rocks and there is no other source of potable freshwater supply except groundwater. Hence, the demand for groundwater is high. To quench this high demand for freshwater supply within the study area, there is need for siting of boreholes that penetrate prolific groundwater zones. Therefore, the present study employed the use of vertical electrical soundings to assess the hydrogeologic potential of the basement terrains of Awe and Akinmorin areas. The electrical resistivity method (VES) is applicable for investigating the subsurface bedrock fractures and for delineating the weathered units develop upon the crystalline bedrocks. VES is commonly used in engineering and hydrogeological investigations for characterising the subsurface lithology within basement terrains (Koefoed, 1979; Ako and Olorunfemi, 1989). It is also applicable for the characterisation of textural attributes of weathered regolith and the state of underlying bedrocks.

\section{LOCATION AND CLIMATE}

Awe and Akinmorin towns are situated at the south-east of Oyo town in Oyo state, SW, Nigeria. It is located within latitudes $3^{\circ} 55^{\prime}$ and $4^{\circ} 00^{\prime} \mathrm{N}$ and longitudes $7^{\circ} 46^{\prime}$ and $7^{\circ} 51^{\prime} \mathrm{E}$. The area is characterised by annual dry and wet seasons. The dry season usually starts in November and ends in March while raining season spans from March to October with average temperatures ranging between $24-26^{\circ} \mathrm{C}$.

The area is largely residential with few smallscale industrial and farming activities. In addition to this, there are a couple of mechanised large scale animal husbandry at Awe. Other facilities such as schools, markets and religious centres are common features in the

areas.

Olanrewaju A. Akanbi, Department of Earth Sciences, Ajayi Crowther University, Oyo, Oyo Town, Nigeria.

Olaitan J. Olukowade, Department of Geology, University of Ibadan, Ibadan, Nigeria. 


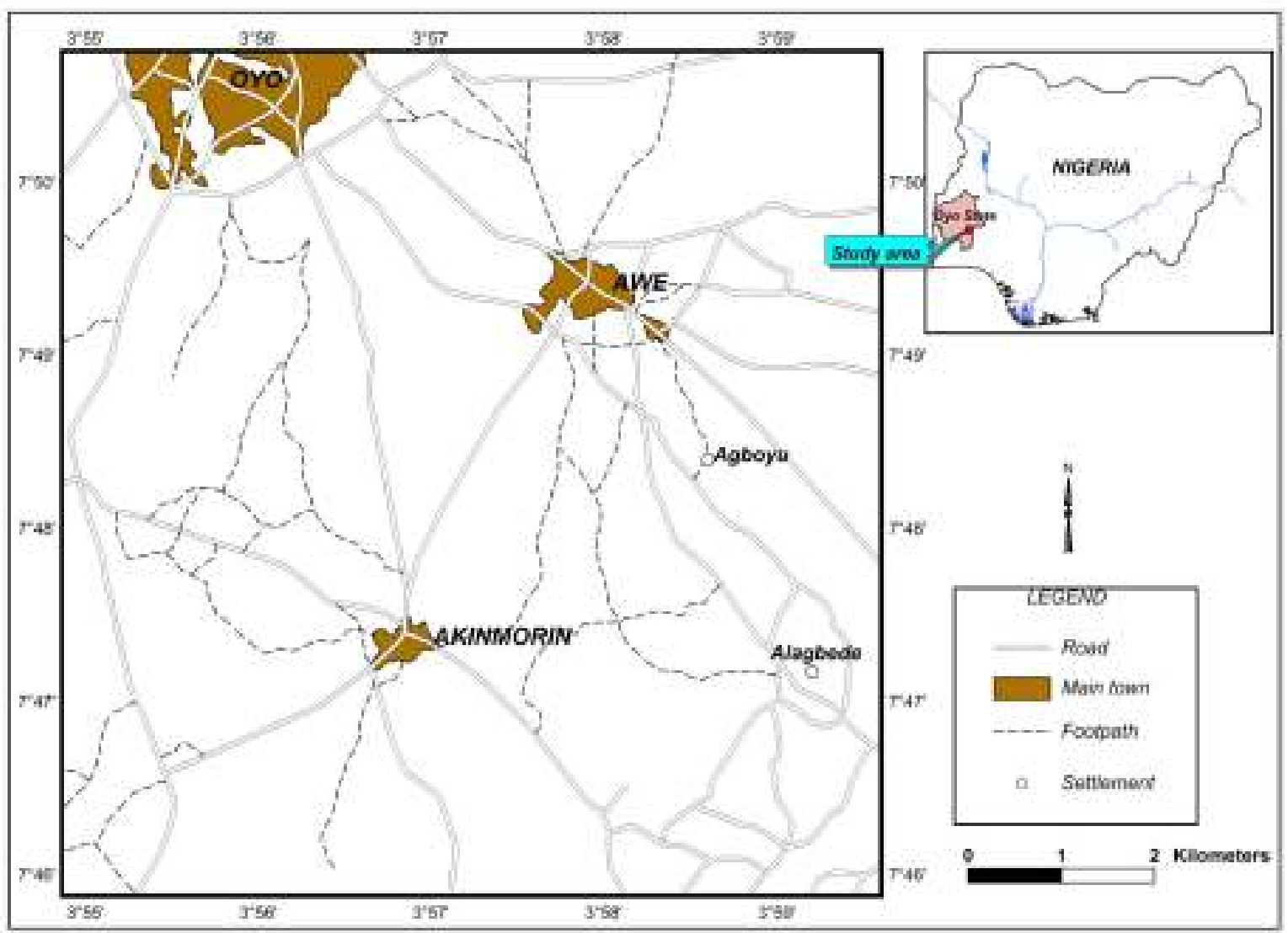

Figure 1: Location map of the study area

\section{GEOLOGY AND HYDROGEOLOGY}

The geology of the area lies within the Precambrian Basement Complex of south-western Nigeria. The main rock types that underlie the area are migmatite, biotite garnet-schist and quartzite (Fig.2). There are also minor occurrences of doleritic dykes, quartz and pegmatite veins that intruded into the main rock bodies.

Normally, intrusive crystalline igneous and metamorphic rocks cannot store and transmit water since they are impermeable. However, adequate waterbearing zones can develop within the weathered and fractured zones. Hence, the weathered zones and rock discontinuities such as fractures and faults are the potential basement aquifers in basement terrains. Usually, the application of VES for investigating the subsurface lithology revealed that in Nigeria the topsoil is normally thin and highly resistive and the thickness is commonly below $2 \mathrm{~m}$. The middle layer that is also known as the saprolite is conductive with the resistivity range of 10 to $200 \mathrm{ohm}-\mathrm{m}$ and thickness less than $50 \mathrm{~m}$, terminating on resistive crystalline bedrocks. When the bedrock is fractured and weathered, the resistivity is often less than $1500 \mathrm{ohm}-\mathrm{m}$, and if the basement rock resistivity exceeded $3000 \mathrm{ohm}-\mathrm{m}$, then the bedrock is fresh and prospect for water is low (Olayinka and Olorunfemi, 1992; Olorunfemi and Olorunniwo, 1990).

Groundwater zones are found in the weathered and fractured zones in basement areas. In Ibarapa area of SW, Nigeria the associated fractured bedrock aquifers were found within the range of $13.6-22.3 \mathrm{~m}$. In areas where bedrock fractures are absent, the weathered layer provided an alternative for groundwater supply. However, the weathered aquifers were describe to be largely unsustainable and are characterised by low transmissivity that are mostly below $1.0 \mathrm{~m}^{2}$ /day (Akanbi, 2017). Additionally, Wright (1992) noted that due to low storativity of basement aquifers there is likelihood of depletion of groundwater during an extended drought in tropical environment such as the study area. Although, prolific wells may also be generated in basement terrains when the regolith is sufficiently thick and the bedrock is fractured. Also, in terrains where the weathered unit is not just thick but fine grained, artesian aquifer may develop if the bedrock is fractured (Akanbi, 2016). 


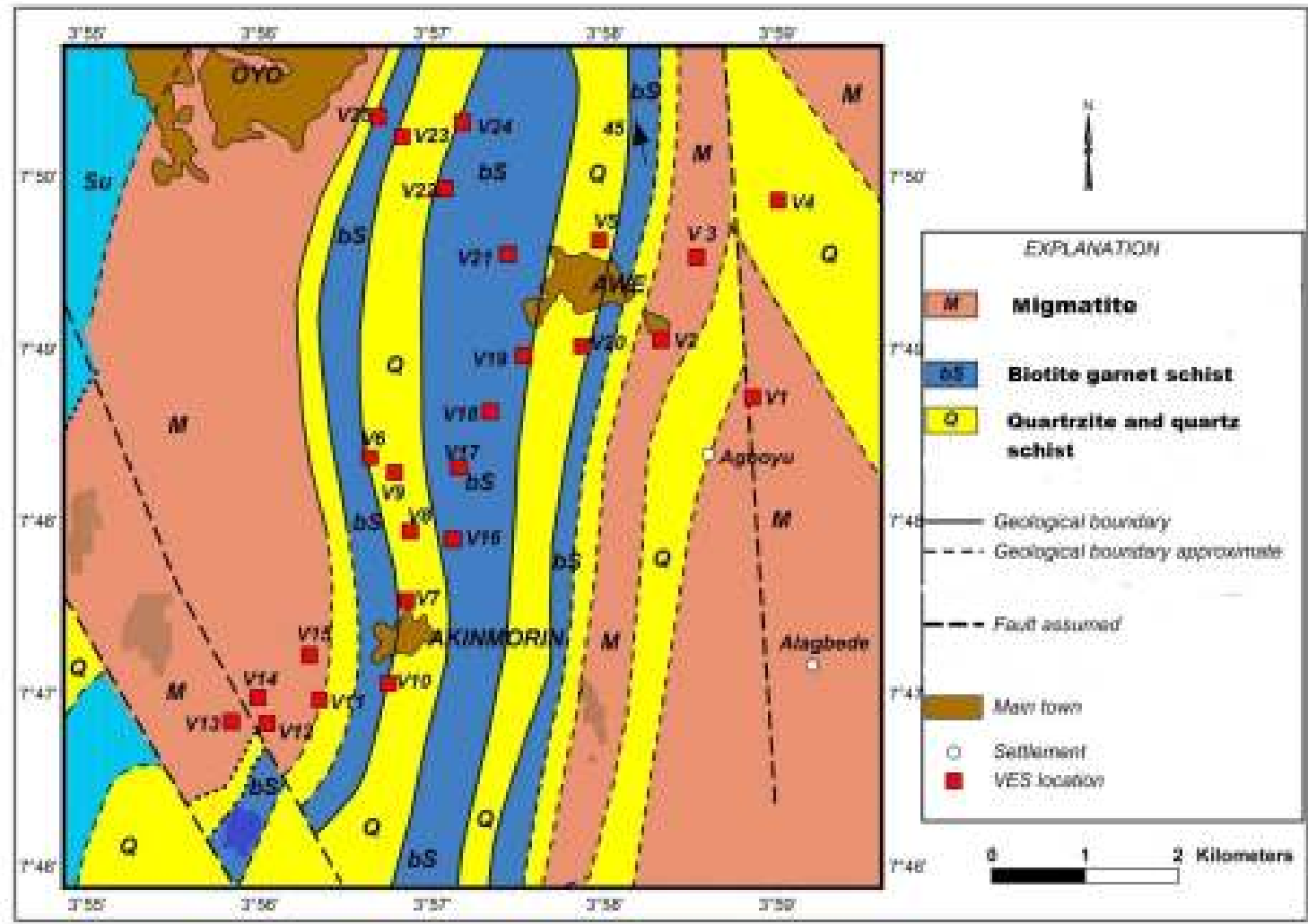

Figure 2: Geology map of the study area (updated from NGSA, 1963), showing the VES points

\section{METHODS AND MATERIAL}

The vertical electrical sounding (VES) has been used extensively in groundwater investigation in the Basement Complex terrains of Nigeria (Barongo and Palacky, 1991; Olayinka and Olorunfemi, 1992; Olorunfemi and Fasuyi, 1993; Akanbi, 2016).

The purpose of electrical surveys is to determine the subsurface resistivity distribution. Artificially-generated currents is introduced into the ground and the resulting potential differences is measured at the surface. From Ohm's law the electrical resistance $R$ of a material is proportional to the length $L$ of the current path and inversely proportional to the area A of its cross section. The constant of proportionality is known as the resistivity, symbolized by $\rho$. Therefore, $R=$ $\rho L / A$, and $\rho=R . A / L$. the unit of resistivity is ohm.length that is ohm.metre.

Deviations from the pattern of potential differences from homogeneous ground provide information on the electrical properties of subsurface heterogeneity. However, rocks conduct electrical current by electrolytic process through the passage of ions in the pore waters within the rock (Keary, et al. 2002). Hence, resistivity is inversely proportional to the porosity and the moisture content of any geological or lithological unit. Thus, resistivity is a variable physical properties in rocks and there will be considerable overlap between different rock types. More so, the resistivity of any material is valid only when the medium is homogeneous and infinite, which is not realistic for subsurface lithological units, since the earth is inhomogeneous and do consist of many distinct units with diverse resistivities. Therefore, the measured field resistivity data are regarded as apparent resistivity, pa. Also, due to resistivity overlap, rock boundary delineation is essential for this present work, and the geological map of the study area is therefore generated as presented in Figure 2.

In as much as this present work focused on the lithological characterisation of bedrock and weathering products, VES geophysical method seems to the most appropriate electrical method, since it has the ability to measure the variations in resistivity with depth. The equipment used for apparent resistivity measurement is ABEM SAS 1000/4000 Terrameter and in order to probe deeper into the subsurface environment, the Schlumberger electrode array was adopted.

Consequently, a total number of twenty-five VES surveys was systematically conducted across the study area. The frequency of distribution of the VES points included; nine VES surveys on quartzite terrains, and eight each on migmatite and within areas underlain by schist. The distribution of the VES points across the bedrock terrains is presented in Figure 2. The current electrodes spread was between 150 - 266m. Quantitative interpretation of the sounding curves was by partial curve matching technique (Zohdy 1965; Orellana and Mooney, 1966; Koefoed, 1979) and computer iteration, using Winresist software (Vander, 2004). The initial primary geo-electric parameters obtained from the partial curve matching technique were 
used as models in computer iteration to obtain the true corresponding layer resistivity and thickness.

\section{RESULTS AND DISCUSSION}

The representative VES curves from iterated apparent resistivity data is presented in Figure 3. The curve types and the quantitative interpretation of the geo-electric parameters as well as the lithologic characteristic are presented in Table 1. The summary of the percentage distribution of the VES curve type is presented in Table 2. The location map of the VES points across the study area is already presented on the geological map in Figure 2.

\section{VES Curves}

Five different curve types were obtained, but the dominant ones were the 3-layer $\mathrm{H}$ type, and 4-layers $\mathrm{KH}$ and QH types (Figure 3). The number of VES curves within these three curve types was twenty-three, which constitute $92 \%$ of all the VES curves represented. From these dominant curves, 3-layer $\mathrm{H}$ type has the highest frequency of occurrence of $48 \%$, while the 4-layers $\mathrm{KH}$ type and the QH-type have $32 \%$ and $12 \%$ frequency occurrences respectively. The other two VES curves are the 4-layer - HK and the 3- layer - A curve types on VES points $\mathrm{V} 1$ and $\mathrm{V} 4$ respectively at Awe area (Figure 2).

\section{Regolith/Weathering Development}

From Table 1, the thickness of regolith units ranges from 11.9 to $50.9 \mathrm{~m}$ on migmatite terrains, 11.8 to $33.7 \mathrm{~m}$ on terrains underlain by schist and 8.5 to $41 \mathrm{~m}$ on quartzite terrains. For these bedrocks terrains, the average total regolith thicknesses were $25.3 \mathrm{~m}, 19.4 \mathrm{~m}$ and

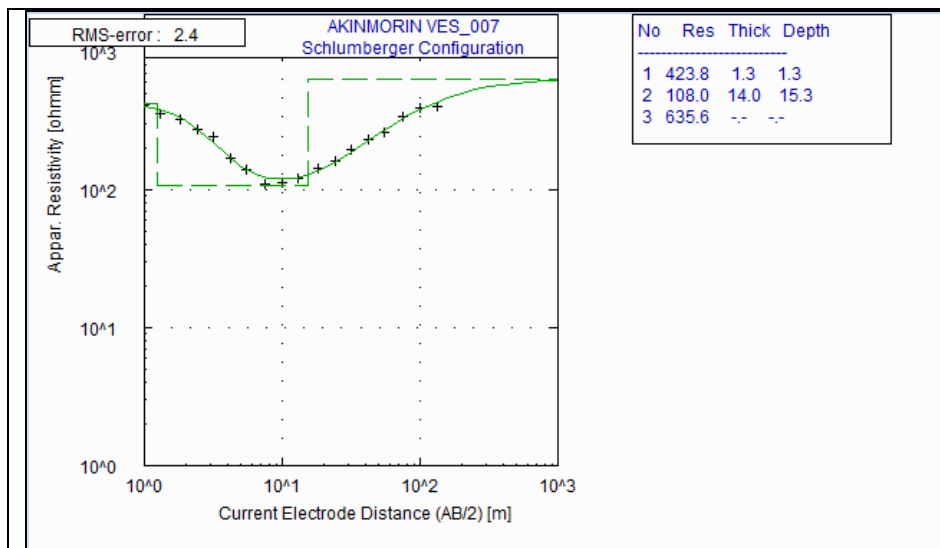

\section{LAYER: H-TYPE}

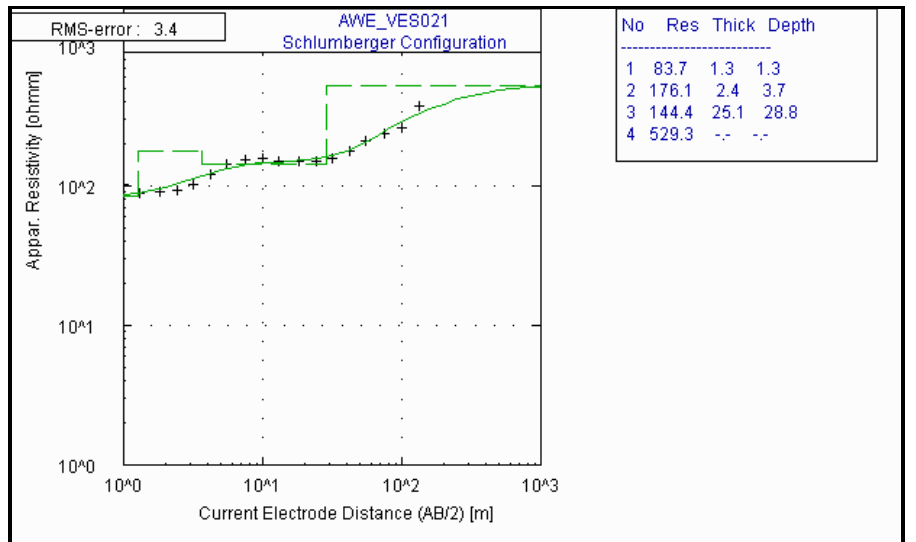

4 LAYER: KH TYPE 


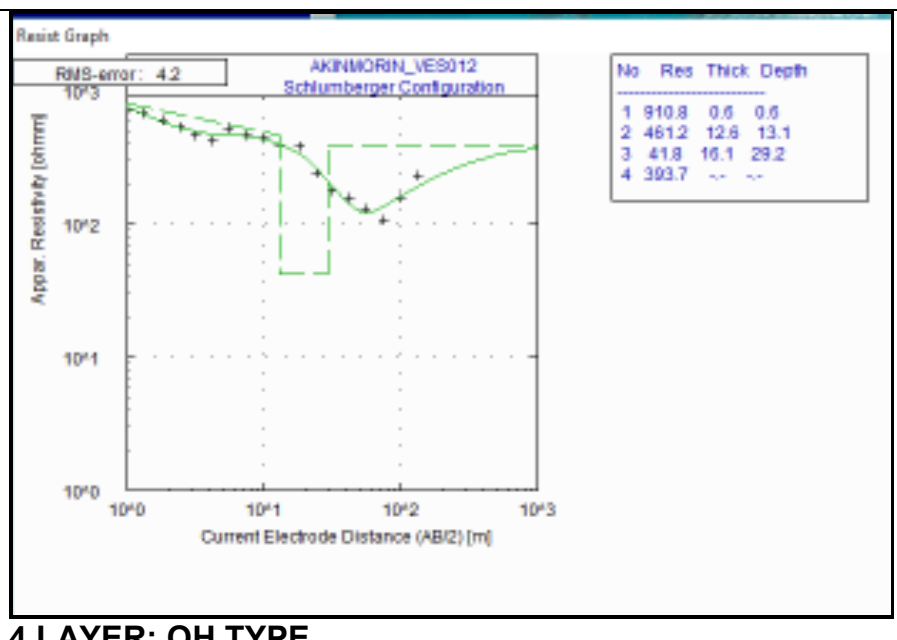

4 LAYER: QH TYPE

Figure 3: Dominant VES curves obtained across the study area

Table 1: Geo-electric Parameters and Lithologic Interpretation

\begin{tabular}{|c|c|c|c|c|c|c|c|c|}
\hline & $\begin{array}{l}\text { VES } \\
\text { Points }\end{array}$ & $\begin{array}{l}\text { Curve } \\
\text { Type }\end{array}$ & $\begin{array}{l}\text { Layer } \\
\text { No. }\end{array}$ & $\begin{array}{l}\text { Thickness } \\
\text { (m) }\end{array}$ & $\begin{array}{l}\text { Resistivity } \\
(\Omega \mathrm{m})\end{array}$ & Lithology & $\begin{array}{l}\text { Regolith } \\
\text { Thickness } \\
\text { (m) }\end{array}$ & $\begin{array}{l}\text { Underlying } \\
\text { Bedrock }\end{array}$ \\
\hline \multirow[t]{4}{*}{1} & VES001 & $\mathrm{HK}$ & 1 & 1.7 & 307.8 & Top Soil & & Migmatite \\
\hline & & & 2 & 9.4 & 37.5 & Clayey & & \\
\hline & & & 3 & 39.8 & 814 & Compacted Clay & 50.9 & \\
\hline & & & 4 & & 14.1 & \multicolumn{2}{|l|}{ Fractured Bedrock } & \\
\hline \multirow[t]{3}{*}{2} & VES 002 & $\mathrm{H}$ & 1 & 1.6 & 644.8 & Top Soil & & Migmatite \\
\hline & & & 2 & 12.8 & 55.6 & Clayey & 14.4 & \\
\hline & & & 3 & & 571.6 & \multicolumn{2}{|c|}{ Slightly weathered Bedrock } & \\
\hline \multirow[t]{4}{*}{3} & VES 003 & $\mathrm{KH}$ & 1 & 0.1 & 334 & Top Soil & & Migmatite \\
\hline & & & 2 & 4 & 525.5 & Compacted Sand & & \\
\hline & & & 3 & 11.9 & 61.1 & Sandy Clayey & 16.0 & \\
\hline & & & 4 & & 2142.2 & \multicolumn{2}{|l|}{ Fresh Bedrock } & \\
\hline \multirow[t]{3}{*}{4} & VES 011 & $\mathrm{H}$ & 1 & 1 & 1144.7 & Top Soil & & Migmatite \\
\hline & & & 2 & 10.9 & 71 & Sandy Clayey & 11.9 & \\
\hline & & & 3 & & 573.7 & \multicolumn{2}{|c|}{ Slightly weathered Bedrock } & \\
\hline \multirow[t]{4}{*}{5} & VES 012 & $\mathrm{QH}$ & 1 & 0.6 & 910.8 & Top Soil & & Migmatite \\
\hline & & & 2 & 12.5 & 461.2 & \multicolumn{2}{|l|}{ Compacted sand } & \\
\hline & & & 3 & 15.1 & 41.8 & \multicolumn{2}{|l|}{ Clayey } & \\
\hline & & & 4 & & 393.7 & Fractured Bedrock & 28.2 & \\
\hline \multirow[t]{3}{*}{6} & VES 013 & $\mathrm{H}$ & 1 & 2.2 & 480.3 & Top Soil & & Migmatite \\
\hline & & & 2 & 11.1 & 39.8 & Clayey & 13.3 & \\
\hline & & & 3 & & 410.2 & \multicolumn{2}{|l|}{\begin{tabular}{|l} 
Fractured Bedrock \\
\end{tabular}} & \\
\hline \multirow[t]{3}{*}{7} & VES 014 & $\mathrm{KH}$ & 1 & 0.3 & 108.2 & Top Soil & & Migmatite \\
\hline & & & 2 & 2.8 & 339.9 & \multicolumn{2}{|l|}{ Sandy } & \\
\hline & & & 3 & 45.4 & 178.1 & Clayey Sand & 48.5 & \\
\hline
\end{tabular}




\begin{tabular}{|c|c|c|c|c|c|c|c|c|}
\hline & & & 4 & & 1954.1 & \multicolumn{2}{|l|}{ Fresh Bedrock } & \\
\hline \multirow[t]{4}{*}{8} & VES 015 & $\mathrm{KH}$ & 1 & 0.1 & 612 & Top Soil & & Migmatite \\
\hline & & & 2 & 1.9 & 1998.2 & \multicolumn{3}{|c|}{ Compacted Lateritic Clay } \\
\hline & & & 3 & 17.3 & 47 & Clayey & 19.3 & \\
\hline & & & 4 & & 1357.3 & \multicolumn{2}{|c|}{ Slightly weathered Bedrock } & \\
\hline \multirow[t]{3}{*}{9} & VES016 & $\mathrm{H}$ & 1 & 4.3 & 304 & Top soil & 21.6 & Schist \\
\hline & & & 2 & 17.3 & 51 & Clayey & & \\
\hline & & & 3 & & 1121.5 & \multicolumn{2}{|c|}{ Slightly weathered Bedrock } & \\
\hline \multirow[t]{4}{*}{10} & VES 017 & $\mathrm{KH}$ & 1 & 0.2 & 177.2 & Top Soil & & Schist \\
\hline & & & 2 & 3 & 228.7 & \multicolumn{2}{|l|}{ Sandy } & \\
\hline & & & 3 & 12.3 & 87.5 & Sandy Clayey & 15.5 & \\
\hline & & & 4 & & 730.9 & \multicolumn{2}{|c|}{ Slightly weathered Bedrock } & \\
\hline \multirow[t]{3}{*}{11} & VES 018 & $\mathrm{H}$ & 1 & 1.3 & 1038.8 & Top Soil & & Schist \\
\hline & & & 2 & 16 & 88.1 & Sandy Clayey & 17.3 & \\
\hline & & & 3 & & 1226.7 & \multicolumn{2}{|c|}{ Slightly weathered Bedrock } & \\
\hline \multirow[t]{4}{*}{12} & VES 019 & $\mathrm{QH}$ & 1 & 0.1 & 878.4 & Top Soil & & Schist \\
\hline & & & 2 & 1.7 & 814.5 & \multicolumn{2}{|c|}{ Compacted Clay } & \\
\hline & & & 3 & 10 & 69 & Sandy Clayey & 11.8 & \\
\hline & & & 4 & & 497 & \multicolumn{2}{|c|}{ Fractured Bedrock } & \\
\hline \multirow[t]{3}{*}{13} & VES 021 & $\mathrm{H}$ & 1 & 1.3 & 83.7 & Top Soil & & Schist \\
\hline & & & 2 & 27.5 & 160.2 & Clayey Sand & 28.8 & \\
\hline & & & 3 & & 529.3 & \multicolumn{2}{|c|}{ Slightly weathered Bedrock } & \\
\hline \multirow[t]{5}{*}{14} & VES 022 & $\mathrm{KH}$ & 1 & 0.3 & 91.5 & Top Soil & & Schist \\
\hline & & & 2 & 0.4 & 289.7 & Sandy & & \\
\hline & & & 3 & 5.2 & 145.6 & Clayey Sand & & \\
\hline & & & 4 & 27.8 & 78.2 & Sandy Clayey & 33.7 & \\
\hline & & & 5 & & 1740.5 & \multicolumn{2}{|l|}{ Fresh Bedrock } & \\
\hline \multirow[t]{3}{*}{15} & VES024 & $\mathrm{H}$ & 1 & 0.6 & 421.9 & Top Soil & & Schist \\
\hline & & & 2 & 11.4 & 97.4 & Sandy Clayey & 12.0 & \\
\hline & & & 3 & & 3931 & Fresh Bedrock & & \\
\hline \multirow[t]{3}{*}{16} & VES 025 & $\mathrm{H}$ & 1 & 1.2 & 1596.9 & Top Soil & & Schist \\
\hline & & & 2 & 12.9 & 65 & Sandy Clayey & 14.1 & \\
\hline & & & 3 & & 2412.5 & \multicolumn{2}{|l|}{ Fresh Bedrock } & \\
\hline \multirow[t]{3}{*}{17} & VES 004 & A & 1 & 0.4 & 91.8 & Top Soil & & Quartzite \\
\hline & & & 2 & 40.6 & 269.1 & Sandy & 41.0 & \\
\hline & & & 3 & & 2634.9 & \multicolumn{2}{|l|}{ Fresh Bedrock } & \\
\hline 18 & VES 005 & $\mathrm{QH}$ & 1 & 0.1 & 118.8 & Top Soil & & Quartzite \\
\hline
\end{tabular}


LITHOLOGIC CHARACTERISATION OF THE BASEMENT AQUIEERS OF AWE AND AKINMORIN AREAS

\begin{tabular}{|c|c|c|c|c|c|c|c|c|}
\hline & & & 2 & 5.7 & 98.9 & Sandy Clayey & & \\
\hline & & & 3 & 18 & 30.6 & Clayey & 23.8 & \\
\hline & & & 4 & & 149 & \multicolumn{2}{|c|}{ Fractured Bedrock } & \\
\hline \multirow[t]{3}{*}{19} & VES 006 & $\mathrm{H}$ & 1 & 2 & 1740.1 & Top Soil & & Quartzite \\
\hline & & & 2 & 14.3 & 121.1 & Clayey Sand & 16.3 & \\
\hline & & & 3 & & 1338.9 & \multicolumn{2}{|c|}{ Slightly weathered Bedrock } & \\
\hline \multirow[t]{3}{*}{20} & VES 007 & $\mathrm{H}$ & 1 & 1.3 & 423.8 & Top Soil & & Quartzite \\
\hline & & & 2 & 14 & 108 & Clayey Sandy & 15.3 & \\
\hline & & & 3 & & 635.6 & \multicolumn{2}{|c|}{ Slightly weathered Bedrock } & \\
\hline \multirow[t]{4}{*}{2} & VES 008 & $\mathrm{KH}$ & 1 & 0.4 & 233 & Top Soil & & Quartzite \\
\hline & & & 2 & 2.2 & 3797.7 & \multicolumn{3}{|c|}{ Compacted Lateritic Clay } \\
\hline & & & 3 & 21.1 & 116.7 & Clayey Sandy & 23.7 & \\
\hline & & & 4 & & 1700.2 & \multicolumn{2}{|l|}{ Fresh Bedrock } & \\
\hline \multirow[t]{3}{*}{22} & VES 009 & $\mathrm{H}$ & 1 & 1.3 & 1414.5 & Top Soil & & Quartzite \\
\hline & & & 2 & 7.2 & 67.8 & Sandy Clayey & 8.5 & \\
\hline & & & 3 & & 10683.1 & \multicolumn{2}{|l|}{ Fresh Bedrock } & \\
\hline \multirow[t]{4}{*}{23} & VES 010 & $\mathrm{KH}$ & 1 & 1.7 & 382.7 & Top Soil & & Quartzite \\
\hline & & & 2 & 2.6 & 429.5 & Compacted Sa & & \\
\hline & & & 3 & 22.9 & 80.8 & Sandy clayey & 27.2 & \\
\hline & & & 4 & & 487 & \multicolumn{2}{|c|}{ Fractured Bedrock } & \\
\hline \multirow[t]{4}{*}{24} & VES 020 & $\mathrm{KH}$ & 1 & 0.2 & 32.9 & Top Soil & & Quartzite \\
\hline & & & 2 & 5.1 & 174.9 & Sandy & & \\
\hline & & & 3 & 14.8 & 75.3 & Sandy Clayey & 20.1 & \\
\hline & & & 4 & & 1046.2 & \multicolumn{3}{|c|}{ Slightly weathered Bedrock } \\
\hline \multirow[t]{3}{*}{25} & VES 023 & $\mathrm{H}$ & 1 & 1.8 & 822.1 & Top Soil & & Quartzite \\
\hline & & & 2 & 23.2 & 76 & Sandy Clayey & 25.0 & \\
\hline & & & 3 & & 466.7 & \multicolumn{2}{|c|}{ Fractured Bedrock } & \\
\hline
\end{tabular}

Table 2: Frequencies of VES Curve Types

\begin{tabular}{|l|l|l|l|}
\hline s/n & VES Curves & $\begin{array}{l}\text { Frequency of } \\
\text { Occurrences }\end{array}$ & $\begin{array}{l}\text { Percentage } \\
\text { Occurrence }\end{array}$ \\
\hline 1 & $\mathrm{H}$ & 12 & $48 \%$ \\
\hline 2 & $\mathrm{KH}$ & 8 & $32 \%$ \\
\hline 3 & $\mathrm{QH}$ & 3 & $12 \%$ \\
\hline 4 & $\mathrm{HK}$ & 1 & $4 \%$ \\
\hline 5 & $\mathrm{~A}$ & 1 & $4 \%$ \\
\hline
\end{tabular}


$22.3 \mathrm{~m}$ respectively. This indicated that the weathering development is more intense when compared to elsewhere on other similar basement terrains such as Igboora where the average regolith thickness is about $15 \mathrm{~m}$ (Akanbi, 2016). However, the extent of weathering is deeper on migmatite terrains compared to other bedrocks within the present study area.

The topsoil has a wide resistivity range and can be said to compose of transported materials collectively referred to as alluvium. Though, the topsoil is not normally exploited for groundwater, the thickness is however important, since the topsoil acts as natural filter for the infiltrating water to other subsurface water bearing zones. The thickness of the topsoil ranges from 2.2 to $0.1 \mathrm{~m}$ at an average of $0.95 \mathrm{~m}$ on migmatite, 4.3 to $0.1 \mathrm{~m}$ at an average of $1.16 \mathrm{~m}$ on schist and 2.0 to $0.1 \mathrm{~m}$ at an average of $1.02 \mathrm{~m}$ on quartzite. Based on the average thickness, the topsoil overlay on terrains underlain by schist is relatively thicker and is more likely to provide better protective shield for the middle layers and the fractured bedrocks that are the main water bearing zones within any basement terrains (Akanbi, 2017).
Lithologic Characterization of the Middle/Saprolite Layers

Locations with more than three geo-electric layers sequence are twelve in number and are characterised by a second or third layer that is made up of either a highly resistive compacted sand or lateritic clay or a moderately conductive layer. The resistivities of compacted sand exceeded $400 \Omega \mathrm{m}$, and where hardpan or compacted clay is encountered the resistivities exceeded $800 \Omega \mathrm{m}$ and can be more than $3000 \Omega \mathrm{m}$. Compacted sandy and clayey units are predominant in migmatite but are also represented in quartzite and schist.

The lithology of the middle (saprolite) layers spans from clayey to sandy. However, the resistivities of the saprolite are mostly below $100 \Omega \mathrm{m}$ and from the lithologic distribution, the middle weathered layer are mostly fine grained (Table 3 ). The fine grained units included the clayey, sandy clayey as well as the compacted lateritic clay lithology, while the clayey sandy components made up the medium grained components. The sandy/gravelly lithology is interpreted as coarse grained. The percentage frequency of these five saprolite lithology is illustrated in Figure 4 in a pie chart.

Table 3: Lithological Distribution of the middle layers (saprolite) by bedrocks

\begin{tabular}{|l|l|l|l|l|}
\hline & \multicolumn{3}{|l|}{ Bedrocks } & \\
\hline Lithology & Migmatite & Schist & Quartzite & $\begin{array}{l}\text { Frequency and Percentage of } \\
\text { occurrence of lithologic units }\end{array}$ \\
\hline Clayey & 5 & 1 & 1 & $7(19 \%)$ \\
\hline Sandy clayey lateritic & 2 & 6 & 5 & $13(35 \%)$ \\
\hline $\begin{array}{l}\text { Compacted } \\
\text { clay/sand }\end{array}$ & 4 & 1 & 1 & $6(16 \%)$ \\
\hline Clayey sandy & 1 & 2 & 3 & $6(16 \%)$ \\
\hline Sandy/gravelly & 1 & 2 & 2 & $5(14 \%)$ \\
\hline
\end{tabular}

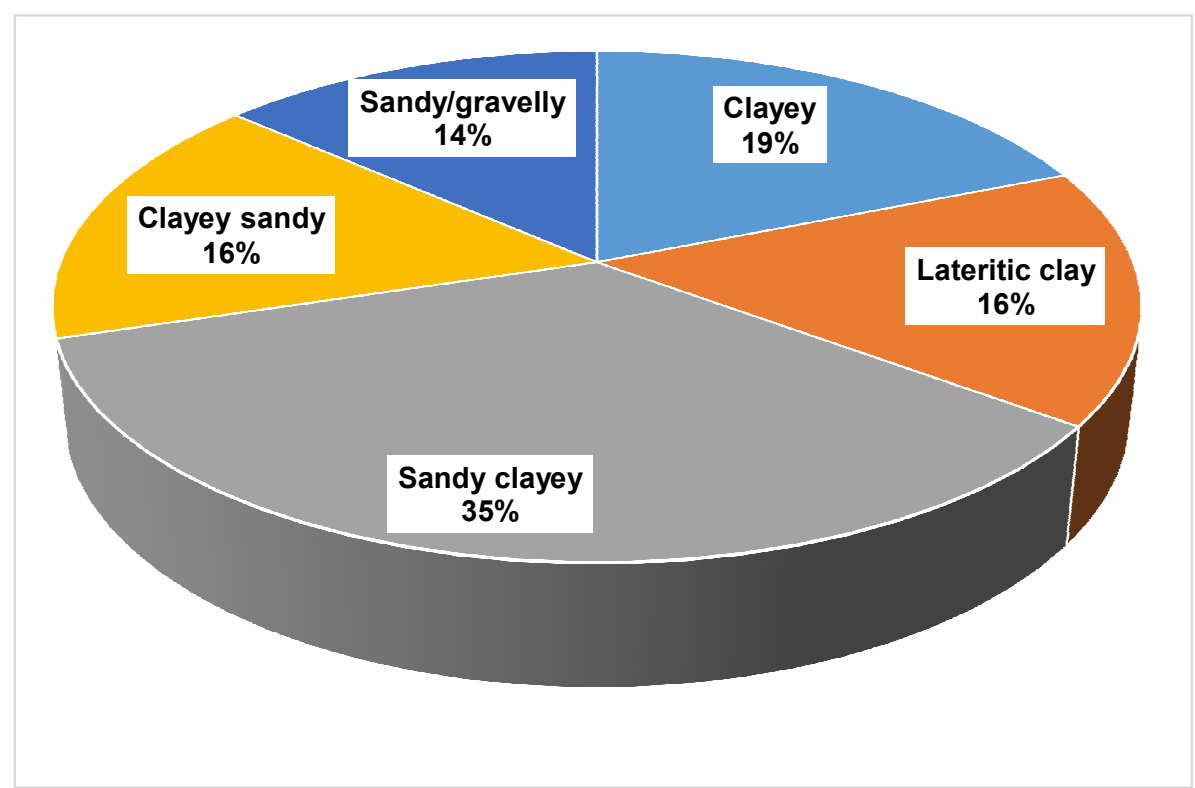

Figure 4: Percentage frequencies of saprolite lithology 
Form the chart (Figure 4), the percentage distribution of the lithology revealed that fine grained saprolite units alone added up to $70 \%$, with a spread of $35 \%$ sandy clayey, $19 \%$ clayey and $16 \%$ lateritic clays lithology. The medium grained/clayey sandy saprolite layer has $16 \%$ occurrence, and the sandy/gravelly saprolite (that is the coarse grained) saprolite units has just $14 \%$ frequency occurrence.

Generally, the most frequently occurring saprolite lithology is the sandy clayey (Table 3, Figure 4) with $35 \%$ occurrence. However, the breakdown of the lithology distribution by bedrock as presented in Table 3 is further illustrated in Figure 5, which revealed the disparity in the degree of weathering process in each bedrock. In migmatite, the saprolite units are dominated by clayey and compacted lateritic clays lithology with close to $70 \%$ occurrence, while in terrains underlain by schist and quartzite, the sandy clayey fraction is the most prominent with over $40 \%$ occurrence in each of these terrains (Figure 5). Comparatively, medium and coarse grained saprolite layers are more frequent in latter terrains than in migmatite bedrock terrains. Also, schist and quartzite terrains have equal proportion of coarse grained sandy/gravelly saprolite faction (Table 3 , Figure 5).

The development of larger percentage of fine grained saprolite or middle layers showed that the degree of weathering is quite intensive across the study area. However, groundwater prospect may be limited within the saprolite layer as a result of widespread fine grained lithology, particularly where the bedrocks are fresh and impermeable.

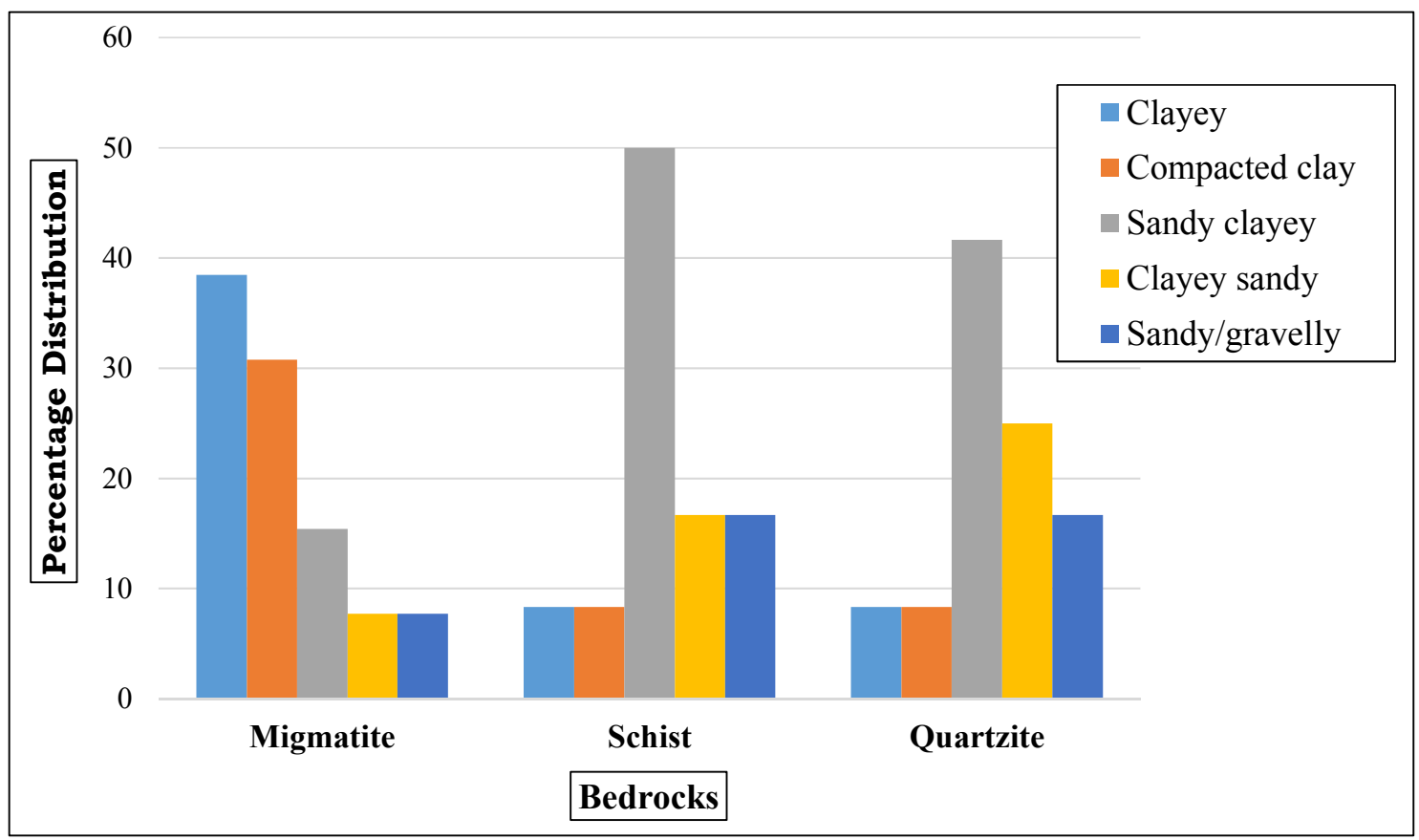

Figure 5: Lithologic distribution of the saprolite units by bedrock

\section{Bedrock Lithology}

The bedrocks of only seven locations with $<500 \Omega \mathrm{m}$ bedrock resistivities were fractured. Fractured bedrocks are not regional controlled but are geologically localised in terrains underlain by migmatite and quartzite (Figure 6) and within the proximity of fault lines and along rock boundary (Figure 2). Bedrock resistivity range between 500 to $1500 \Omega \mathrm{m}$ are interpreted as slightly or partially weathered bedrocks, and are the commonest bedrock lithology category across the study area. This is because ten out of twenty-five locations were found to be underlain by less competent basement rocks that are regarded as weak. These weak bedrocks are found to be associated with the three bedrock terrains, but are more frequent in areas underlain by schist (Figure 6). Aside fractured bedrocks, weak bedrocks are also capable of transmitting groundwater into nearby wells, though are not as productive as the former bedrocks (Akanbi, 2017). Only eight bedrocks are characterised by resistivity of more than $1500 \Omega \mathrm{m}$ across the study areas and are interpreted as fresh bedrocks. Locations underlain by fresh bedrock spread across the three rock type terrains, but are less frequent in migmatite. Areas whose bedrocks are fresh and are neither fractured nor weathered are expected to have low groundwater prospect. However, in locations where the regolith thickness is high and the middle layer is conductive, the saprolite can provide an alternative for groundwater exploitation, though, the yield may be lower compared to that of fractured bedrocks. 


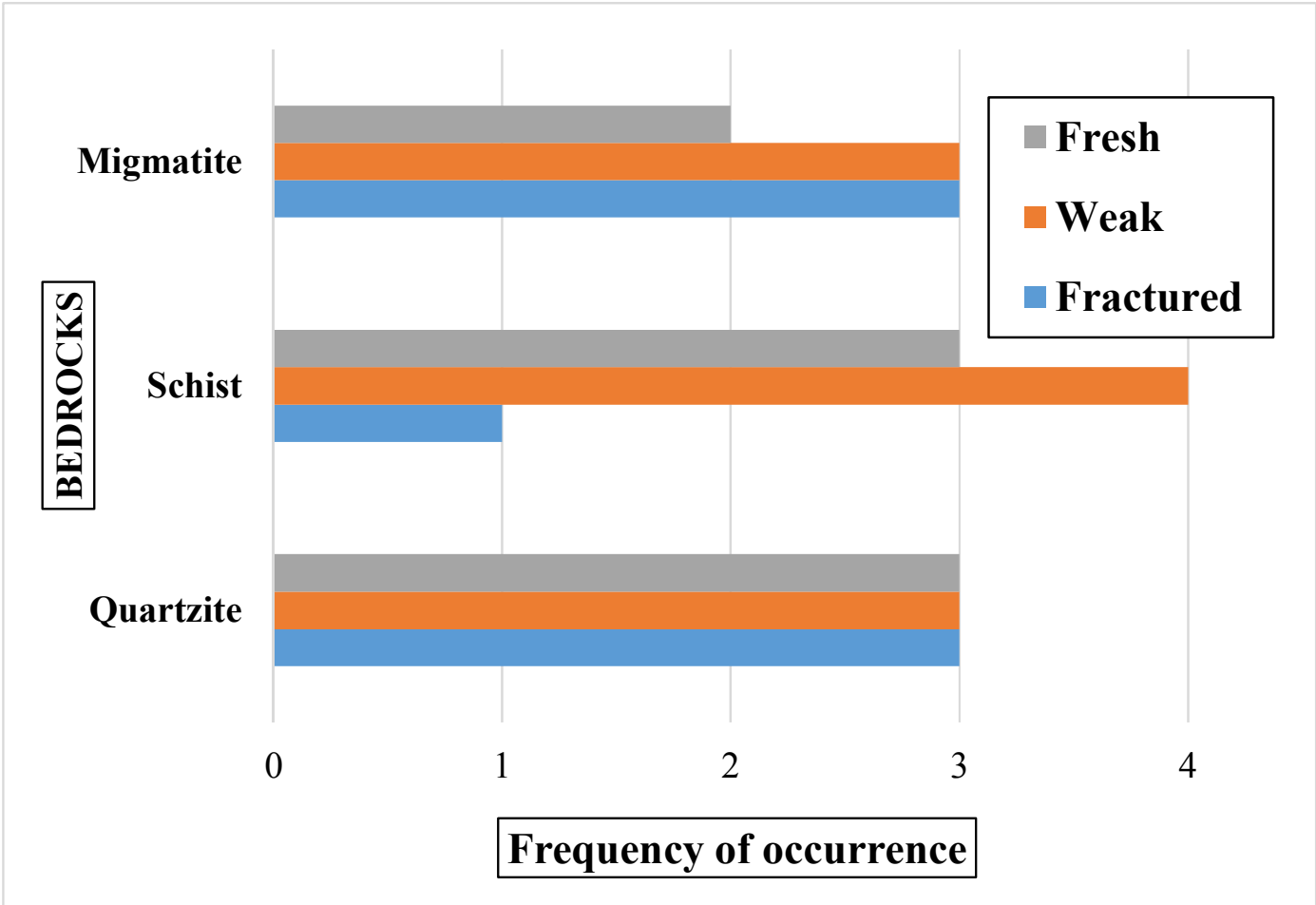

Figure 6: Frequency distribution of the state of bedrock across the study area

It is obvious there is variations in bedrock lithology, even on the same bedrock terrains (Figure 6). For example, on quartzite terrains one-third of the bedrock is fractured, one-third is slightly weathered and the last one-third is fresh bedrock with little or no groundwater potential (Figure 6). On the other hand, schist bedrocks are more weathered than fractured, half of the bedrocks are slightly weathered, while the bedrock of only one location is fractured and the rest of the locations are underlain by fresh schist bedrock. On migmatite terrains, three bedrocks are fractured, another three are weak while the last two bedrock are fresh migmatite bedrocks. This disparity in bedrock lithology and in weathering development is expected to bear imprints on groundwater prospect across the study area.

\section{CONCLUSION}

Groundwater prospect in Awe and Akinmorin areas is expected to be localised and varied as a result of variations in the degree and extent of weathering as well of bedrock fracturing. These two towns are mainly underlain by schist and quartzite, while the adjoining area at the eastern and western parts are migmatite bedrock terrains. In respect of groundwater prospect of the middle layers alone, areas underlain by schist and quartzite will provide wells with better yield. This is because the saprolite units in these duo bedrocks are characterised by more sandy lithology, compared to locations underlain by migmatite whose middle layers are more clayey. Though, the clayey faction are conductive, the water transmission is poor. However, fractured bedrocks that are reputable to be the dominant water bearing zone in any basement terrains are not widespread across the study area. The bedrocks of just seven locations are fractured and are mainly found in terrains underlain by migmatite and quartzite. Some of the fracture zones are found to occur either on or close to the two fault zones that cut through the migmatite and quartzite terrains. Hence, occurrence of fractured bedrocks within these two bedrocks is actually facilitated by proximity to fault line. The spread of the fractured zones is approximately the same at Awe and Akinmorin. The only fractured bedrock associated with the schist terrains is on VES019, which is close to Awe town.

The saprolite layers can also be exploited for groundwater as a result of deep weatherig acrosss the study area. This is more so within the quartzite and schist areas where the middle layers are coarser and fairly conductive. is more coarser and fairly conductive. Contrastingly, groundwater potential of the saprolite aquifers is expected to be low within the migmatite terrains due to thick fine grained texture. However, where the bedrock is fractured, the thick fine grained saprolite units become the confining layers to the prolific bedrock. Therefore, the likelihood of occurrence of confined aquifers is high within the study area, particularly in locations where the thick fine grained saprolite layer overlies the fractured bedrocks.

Additionally, the largely fine grained weathered layer will prevent the enclosed groundwater in the lower subsurface aquifers from being contaminated via direct recharge. Also, due to the thickness of the regolith, the overburden can also be exploited for groundwater where the saprolite is coarse enough to transmit water. This is feasible in locations underlain by quartzite where the lithology is more sandy. This only contraint is that the 
saprolite aquifer will be prone to contamination from direct recharge of land surface run-off.

\section{REFERENCES}

Akanbi, O. A., 2017. Hydrogeologic characterisation of crystalline basement aquifers of part of Ibarapa area, southwestern Nigeria. Unpublished Ph.D. thesis $312 p$. University of Ibadan.

Akanbi, O. A., 2016. Use of vertical electrical geophysical method for spatial characterisation of groundwater potential of crystalline crust of Igboora area, southwestern Nigeria. International Journal of Scientific and Research Publications 6.3: 399-406.

Ako, B. D and Olorunfemi, M. O., 1989: Geoelectric survey for groundwater in the newer basalts of Vom, Plateau state. J. Min. Geol. 25, (1\&2): 247-250.

Barongo, J. O and Palacky, G. J., 1991. Investigations of electrical properties of weathered layers in the Yala area, Western Kenya using resistivity soundings. Geophysical. 56, (0.1): 133-138.

Jones, H. A and Hockey, R. D., 1964. The geology of parts of southwestern Nigeria. Geological Survey of Nigeria. Bulletin 31, pp: 22-24.

Keary, P., Brooks, M and Hill, I., 2002. An introduction to geophysical exploration, Third edition; Blackwell Science Ltd.

Koefoed, O., 1979. Geosounding Principles I: Resistivity sounding measurements. Amsterdam: Elsevier Scientific publ.

Manda, A. K., Mabee, S. B and Boutt, D. F., 2006. Characterizing fractured crystalline bedrock aquifers using hydrostructural domains in the Nashoba Terrain, Eastern Massachusetts. In Proceeding of 2006 Amsterdam meeting of the Geological society of America, Philadelphia, Pennsylvania, 22-25.
Olayinka, A. I and Olorunfemi, M. O., 1992. Determination of geo-electrical characteristics in Okene area and implication for boreholes setting. J. Min. Geol. 28, 403-412.

Olorunfemi, M. O and Fasuyi, S. A., 1993. Aquifer types and geo-electric/hydrogeologic characteristics of part of Central basement terrain of Nigeria (Niger State). J. Africa. Earth Science., 16, (3): 309-317.

Olorunfemi, M. O and Olorunniwo, M. A., 1990. The determination of the geo-electric parameters of some Nigerian residual and detrital clays. Journal of Mining and Geology, 26.1: 81-85.

Orellana, E and Mooney, H. M., 1966. Master Tables and curves for vertical electrical sounding over layered structures: Madrid Interciecia, Geophysics 28: 99-110.

Singhal, B. B. S and Gupta, R. P., 1999. Applied hydrogeology of fractured rocks. Dordrecht, The Netherlands: Kluwer Academic Publishers.

Vander, V. B. P. A., 2004. WINRESIST Version 1.0. M.Sc. Research project. ITC, Delft, Netherlands.

Wright, E. P., 1992. The hydrogeology of crystalline basement aquifers in Africa. In: Wright, E.P and Burgess, W.G.(eds). The hydrogeology of crystalline basement aquifer in Africa. Geol Society Special Publication, 66:1-29

Zohdy, A. A. R., Eaton, G. P and Mabey, D., 1974. Application of surface geophysics to groundwater investigations. Techniques of water resource investigations of USGS, Washington, 60. 